\title{
ツイストローラ方式摩擦駆動による 精密位置決め機構の研究*
}

\author{
水本 洋** 野村克己*** 松原十三生 ${ }^{\dagger}$ 牧本良夫 ${ }^{\dagger}$
}

A Precision Positioning System Using a Twist-Roller Friction Drive

Hiroshi Mizumoto, Katsumi Nomura, Tomio Matsubara and Yoshio Makimoto

For sub-micrometer and nanometer order positioning, a twist-roller friction drive is proposed. With a small twist angle, three driven rollers supported by a hydrostatic bearing system are pressed against a driving shaft. As the shaft rotates, the rollers rotate and move in their axial direction. This axial motion is used for positioning. The axial displacement of the rollers per one revolution of the driving shaft is equivalent to the lead of a screw. Within $\pm 0.1 \mathrm{~mm}$, the lead of the twist-roller friction drive can be changed by controlling the oil supply pressure for the hydrostatic thrust bearings which support the axial direction of the rollers. Therefore, nanometer positioning can be realized by using a driving motor having the resolution of only tens of thousands pulses/revolution. The twist-roller friction drive is incorporated into a table which is guided by a hydrostatic slideway. Measured characteristics such as the lead, submicrometer step feed, and closed loop positioning of the table are shown.

Key words: friction drive, hydrostatic bearing, nanometer positioning, sub-micrometer positioning, twist-roller friction drive

\section{1.はじめに}

摩擦駆動による位置決め機構はロストモーションが 少なく，適当なフィードバック制御を行うことで高い 精度が実現でさることより, 精密工作機械, 3 次元測 定機などに採用され始めている。これまでにこの種の 目的に実用化されている摩擦駆動装置は駆動軸と従動 軸の軸線が直交した，ラック・アンド・ピニオン方式 であり,・ード（駆動軸 1 回転による従動軸の移動 量）は数十 $\mathrm{mm}$ になるのが普通である ${ }^{1) \sim 5)}$. したがっ て, 超精密工作機械などで必要となる $10 \mathrm{~nm}$ オーダ の最小設定単位を実現するには数百万分の 1 回転の分 解能で駆動軸を制御する必要がある.

摩擦駆動の方法としてはこのほかにッイストローラ 方式と呼ばれるものがある. この方式は駆動軸に従動 軸を適当な交差角で押し付け, 駆動軸の回転によって 従動軸に生じる回転運動に伴う軸方向の運動を利用し て送り動作を行うもので, 機構的にはねじ送りに相当

\footnotetext{
* 原稿受付 平成 3 年 2 月 13 日. 1990 年度精密工学会秋 季大会学術講演会 (平成 2 年 9 月 30 日) にて発表

** 正会員 鳥取大学工学部 (鳥取市湖山町南 4-101)

*** 学生会員 鳥取大学工学部

†正会員 名古屋工業大学 (名古屋市昭和区御器所町)

††正会員 (株)不二越（滑川市大掛 176）
}

する. ツイストローラ方式では交差角を微少とするこ

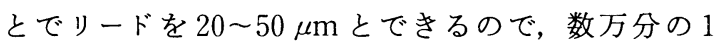
回転の分解能の駆動モータでナノメータオーダの微少 送りが可能であり，原理的には超精密工作機械への使 用に適していることがわかる。しかしながらッイスト ローラ方式での送り精度には従動軸の回転精度が影響 するために, 従来は従動軸を転がり軸受で支持した製 品が，あまり精度を必要としない産業用機械の送り装 置などに使用されていだ).

そこで我々は，ッイストローラ方式による高精度の 位置決め機構を実現するために，従動軸の支持に静圧 軸受を採用した。この位置決め機構では静王軸受の使 用により従動軸の回転精度が向上するほか, 均一な予 圧が実現できること、リードの調節が可能であるこ と, 駆動軸と従動軸の接触部への潤滑が充分行えるこ となどの効果が期待できる．本論文では静圧軸受を使 用した摩擦駆動装置の機構を示すとともに, リード, ステップ送りなどの特性を解析して，ッイストローラ 方式によるナノメータオーダ精度の位置決め機構の実 現をめざす。

\section{2. ツイストローラ方式摩擦駆動の原理}

摩擦駆動においては，駆動軸に従動軸がある予区で 


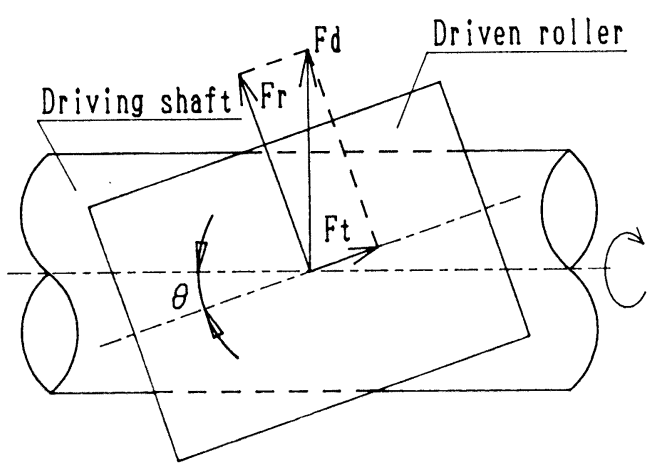

Fig. 1 Driving shaft and driven roller of twist-roller friction drive

押し付けられ，両軸の接触部における摩擦力を介して 駆動軸の回転運動が従動軸の直線運動あるいは回転運 動に伝達される。したがって，摩擦駆動における送り 方向の負荷容量は, 予圧と接触部のすべり摩擦係数の 積で与兄られる.駆動軸と従動軸の軸線の交差角を $\theta$ とすると, $\theta=90^{\circ}$ の場合には従動軸はその軸線方向 に直線運動のみを行らことになる．このような配置が 従来より摩摖駆動位置決め装置に採用されてきたラッ ク・アンド・ピニオン方式である. 一方， $\theta=0^{\circ}$ にする と従動軸は回転運動のみを行い, 位置決め動作に必要 な従動軸の軸線方向への直線運動は生じない。そこ で，図 1 に示すように $\theta$ を $0^{\circ}$ から $90^{\circ}$ の間の適当な 角度に設定すると，従動軸は回転運動と軸線方向への 直線運動とを同時に行ら。つまり従動軸は駆動軸の周 りをつるまき角 $\theta$ のつるまき線を描さながら転がる ことになる，このつるまき線を展開すると图 2 のよう になり，機構的には㸚じ送りに相当することがわか る. このよらに $0^{\circ}<\theta<90^{\circ}$ に配置する方式をッイス トローラ方式と呼ぶこととする.

ラック・アンド・ピニオン方式では従動軸は位置決 め動作に必要な軸方向の直線運動のみを行らので, 機 構が簡単であり高精度が期待できる．また，駆動軸径 を $D$ とするとリード $L=\pi D$ となり， $D$ が数十 $\mathrm{mm}$ であればリードは数十一百 $\mathrm{mm}$ になるために比較的 高速の位置決め動作が可能となる反面, ナノメータ オーダの位置決め分解能を得るには数百万分の 1 回転 の分解能で駆動軸の回転を制御する必要がある.

それに対してッイストローラ方式では図 2 に示すよ らにリード $L=\pi D \tan \theta$ となるので， $\theta$ を変えるこ とによりリードは 0 数十 $\mathrm{mm}$ の範囲で適当に設定す ることが可能である. 通常の送り权じでのリードを 1 $\mathrm{mm}$ 以下とすることは困難であるが，ツイストローラ 方式では交差角 $\theta=10^{-4} \mathrm{rad}$ 程度に設定することで

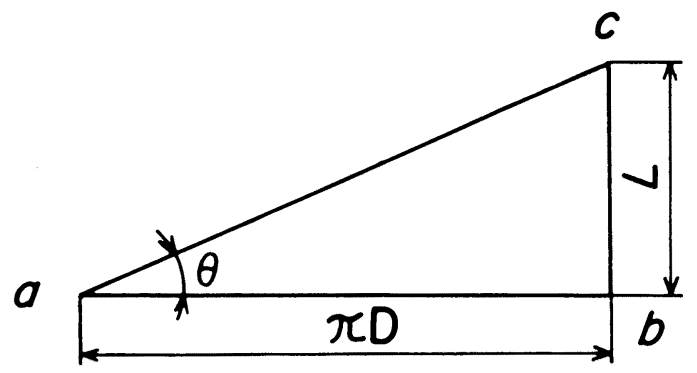

Fig. 2 Development of roller locus

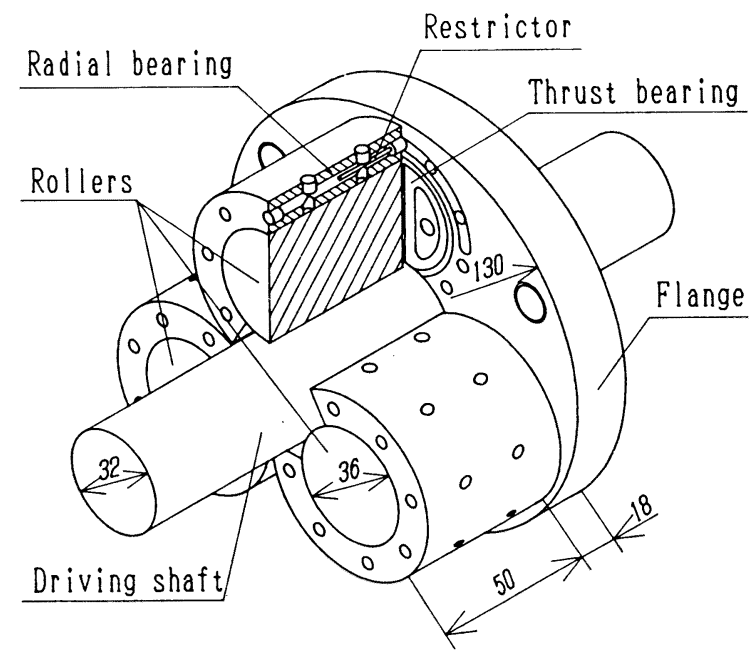

Fig. 3 A twist-roller friction drive

リードを数十 $\mu \mathrm{m}$ とできるので，駆動軸を数万分の 1 回転の分解能で制御することでナノメータオーダの位 置決め分解能が得られる. しかしながら従動軸は位置 決め動作には不必要な回転運動も行うことになるの で，この回転運動が位置決め動作に悪影響を及ぼさな いように従動軸を高精度で支持する軸受システムを組 み込むことがッイストローラ方式による精密位置決め 機構を実現するための必要条件となる.

\section{3. 試作摩擦駆動位置決め装置}

図 3 には試作した位置決め装置のッイストローラ摩 擦駆動部を示す. 直径 $32 \mathrm{~mm}$ の駆動軸の周りに直径 $36 \mathrm{~mm}$, 長さ $50 \mathrm{~mm}$ の従動軸となるローラが $120^{\circ}$ 間 隔で 3 個配置されている. これらの駆動軸と従動口ラはすべて軸受鋼を焼さ入れ後, 研削仕上されたもの である，位置決め動作に対する従動軸の回転運動の影 響を少なくするために，ここでは潤滑油を作動流体と する静圧軸受により従動ローラを支持する構造とし た.

まずローラのラジアル方向の支持については，上側 


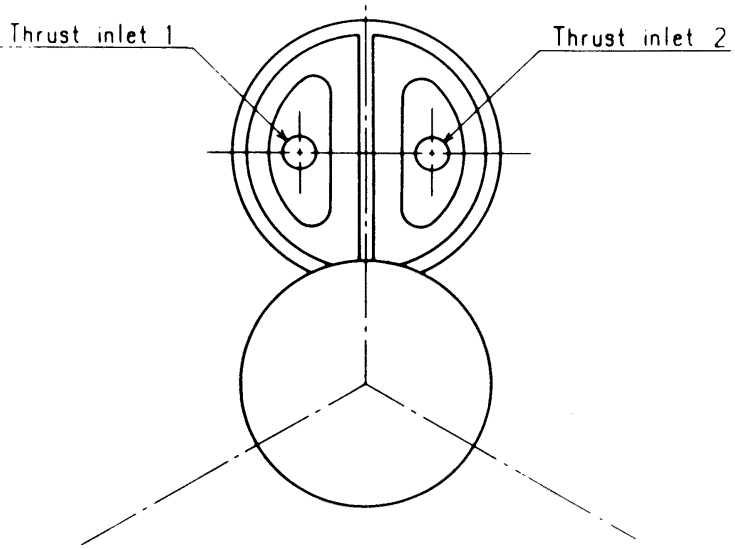

Fig. 4 Roller-supporting thrust bearing surface

のローラ部断面に示すように，静圧ラジアル軸受が用 いられている. このラジアル軸受の駆動軸側は切り欠 かれて拈り，ローラを駆動軸に押し付ける構造となっ ている. 図中に示すようにローラ支持及び駆動軸への 予圧に有効な給油孔は円周 5 か所，2 列設けられてお り，それぞれの給油孔には毛細管絞りを介して圧力油 が供給される。このように静圧軸受を用いることで ローラの回転精度を向上させるとともに，駆動軸と従 動軸との接触部への潤滑, 予圧の調節と均一化を容易 に実現できる、軸受への作動油供給王は $2 \mathrm{MPa}$ とし, このときの最大予圧は約 $6 \mathrm{kN}$, ローラと駆動軸との 接触部の最大 Hertz 応力は約 $0.4 \mathrm{GPa}$ となる.

一方, ローラのスラスト方向の支持にはフランジ面 に加工された静圧スラスト軸受を用いた。図 3 には奥 側のフランジのみが示されているが，同じ形式の軸受 が手前側にも組み付けられるので，この静圧スラスト 軸受は対向型として機能する. スラスト軸受面は図 4 に示すように左右に分かれて打り，それぞれの軸受面 のポヶットには外部に設置した絞りを経て独立した圧 力 $P_{1}$ および $P_{2}$ の作動油が供給される. そして $P_{1}$ と $P_{2}$ の比を変えることにより駆動軸と従動ローラとの 交差角 $\theta$ を変えることができる，静圧ラジアルおよ びスラスト軸受の基準油膜厚さは $40 \mu \mathrm{m}$ であるので, 駆動軸とローラとの交差角 $\theta$ は最大 $10^{-3} \mathrm{rad}$ 程度に 設定できる.

図 3 に示すようにツイストローラ摩擦駆動部は送り ねじのナット部に機能的にも形状的にも良く似ている ので，位置決め装置への組込みもナットの場合と大差 ない. 図 5 は摩擦駆動部を組み込んだ位置決め装置で ある. フランジ (7)の外側にはサイドプレート (8) が取 り付けられて移動テーブルを構成している. サイドプ レートの両端には案内用の静圧ラジアル軸受 (4) が取

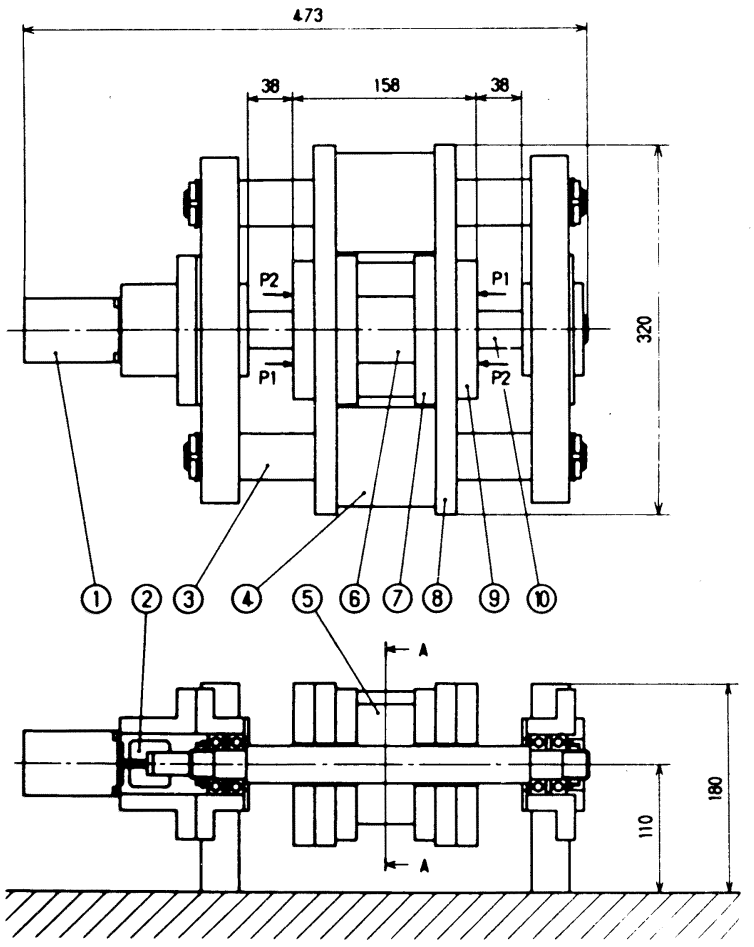

Fig. 5 Feed drive system with the twist-roller friction drive

1 ; motor, 2 ; coupling, 3 ; guide bar, 4 ; guide bearing, 5 ; driven roller, 6 ; radial bearing, 7 ; flange, 8 ; side plate 9 ; cover, 10 ; driving shaft

り付けられており, 案内軸 (3)により移動テーブルが 案内される. 駆動軸 (10) はカップリング (2) を介してパ ルスモータ (1) と結合されている.このパルスモータ はマイクロステップ駆動が可能であり, 1 回転を最大 204800 分割することができる.な怙駆動軸の支持に は転がり軸受を使用した。

図 6 には摩擦駆動位置決め装置の制御システムのブ ロック線図を示す. 制御用マイクロコンピュータの指

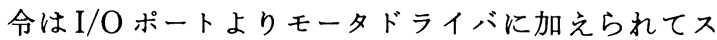
テップモータを駆動する. テーブル移動量は, 測定に 必要な精度と範囲に応じて, 差動変圧器式電気マイク ロメ一タ（分解能 $0.1 \mu \mathrm{m}$, 摩擦範囲土200 $\mu \mathrm{m}$ ), あ るいは容量型変位計（分解能 $0.01 \mu \mathrm{m}$, 測定範囲 50 $\mu \mathrm{m})$ により検出される. クローズドループによる フィードバック制御を行らときには，このテーブル移 動量が $\mathrm{A} / \mathrm{D}$ 変換されてコンピュータにフィードバッ クされ，テーブルの実際の位置と目標位置とに差があ れば, I/O ポートより修正信号がモータに出されて テーブル位置が修正される。このような修正動作は, テーブルの実際位置と目標位置との差があらかじめ設 定された数值（これを設定分解能と呼ぶ）以内になる 


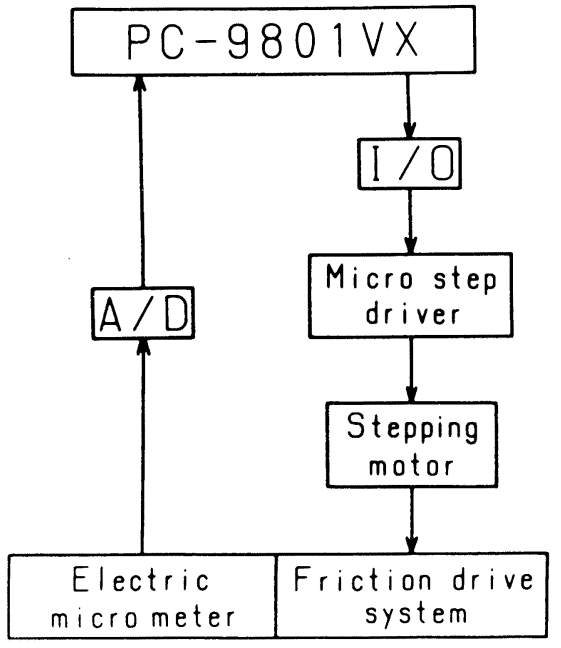

Fig. 6 Block diagram of control system

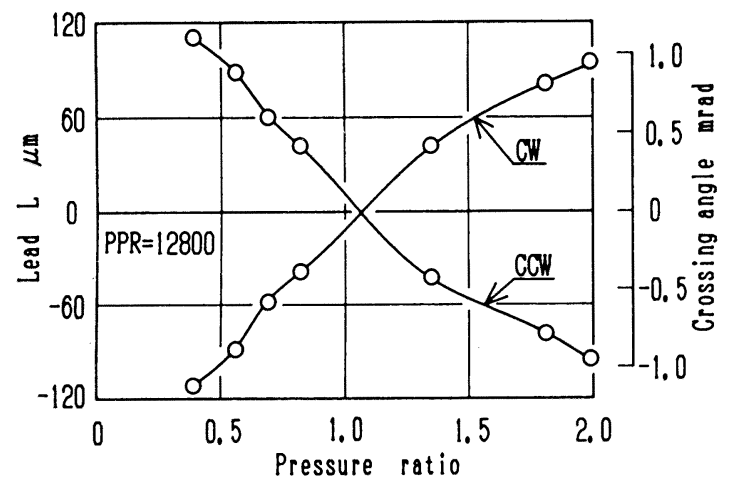

Fig. 7 Lead of the twist-roller friction drive

まで繰り返される.

\section{4. 位置決め特性の解析}

\section{1 リードの測定}

図 7 はパルスモータの分割数を 12800 とし，スラ スト軸受への供給圧力比 $P_{1} / P_{2}$ を変えたときのリード の変化を電気マイクロメータにより測定した結果であ る（ただしここでは 400 パルス当たり，つまり1/ 32 回転での移動量を測定してリードに換算した). 各 点は 30 回の測定の平均である. このリードの測定に おいては制御コンピュータは修正信号を出さず，オー プンループによる制御を行っている. 図 7 より $P_{1} /$ $P_{2}=1$ のときは交差角が零となるためにリードは零で ある. 圧力比を変学ることで交差角が生じ, 駆動軸の 回転方向が同じCW あるいは CCW のままであって もリードは土100 $\mu \mathrm{m}$ の範囲で調節可能であることが わかる。このとき, 交差角 $\theta$ は土 $10^{-3} \mathrm{rad}$ 範用で 変化していることになる．ただし，圧力比を 1 に近づ

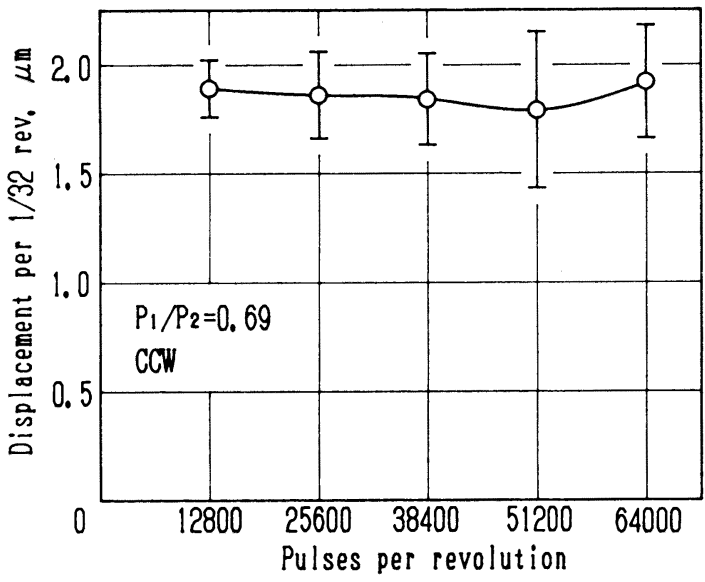

Fig. 8 Influence of motor resolution

けて小さい交差角を設定すると送り動作が不安定と なったので, 以下の実験では圧力比 $P_{1} / P_{2}=0.69$ とし てリードを $60 \mu \mathrm{m}$ 程度に設定した.

次にモータ分割数の影響を調べた。 図 8 には圧力比 $P_{1} / P_{2}=0.69$ とし， $1 / 32$ 回転当たりの移動量をそれぞ れの分割数ごとに 30 回測定したときの平均値と標準 偏差を示す.どの分割数の場合も平均移動量は 1.8 $\mu \mathrm{m}$ 程度（リードに換算すると $58 \mu \mathrm{m}$ ) で安定して いたが, 標準偏差 $0.1 \sim 0.3 \mu \mathrm{m}$ 程度のばらつきが あった. このよらに同一の指令值に対して実際の移動 量がばらつく最大の原因は摩摖駆動に伴う駆動軸と従 動軸との接触部での滑り現象の不安定性のためと考光 られる.これは摩擦駆動に拈いては不可避の現象であ る. また, 作動油の圧力変動による圧力比 $P_{1} / P_{2}$ の微 少変化も移動量のばらつく原因となる. したがって, 摩擦駆動によりサブミクロンの位置決めを行らには図 6 に示すようなクローズドループ制御を行ら必要があ る.

図 9 には図 8 をもとに 1 パルス当たりの移動量を計 算した結果を示すが，この圧力比では駆動軸を約 5 万分の 1 回転で制御することにより 1 パルス当たりの 移動量を $1 \mathrm{~nm}$ とできることになる. したがって，従 来の送りねじやラック・アンド・ピニオン方式の摩擦 駆動を用いた位置決め機構に招いてナノメータオーダ の位置決め分解能を得るには駆動モータを百万分の 1 回転の分解能で制御しなければならないことと比較し て, ここで示したツイストローラ方式では駆動モータ の制御が容易であることがわかる. このことは駆動軸 支持軸受の精度や駆動モー夕特性の安定性などの影響 を受けにくい精密位置決め機構の実現につながる.あ るいは, 分解能が百万分の 1 回転の駆動モータを使用 すれば, サブナノメータの位置決め機構の実現をめざ 


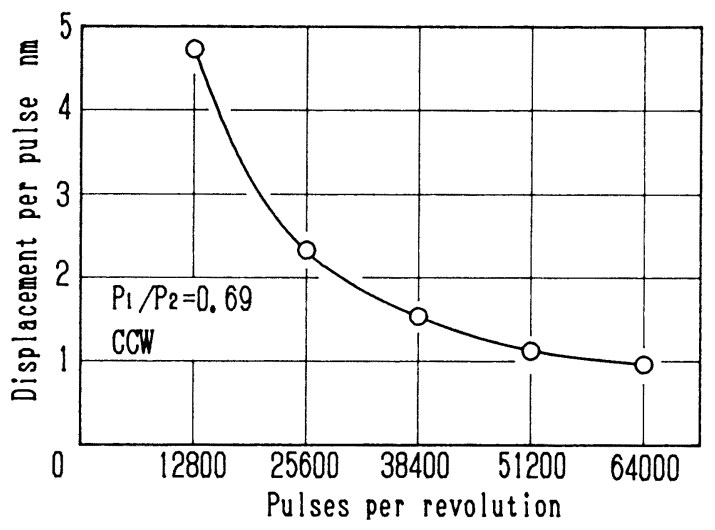

Fig. 9 Calculated resolution of the twist-roller friction drive

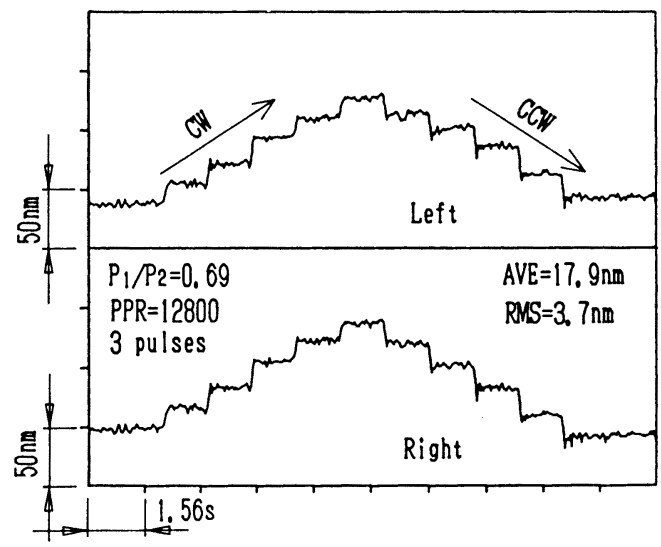

Fig. 10 Open-loop step feed of the twist-roller friction drive

すことも可能となるであろう，ただし，そのためには 位置決め機構の部品精度, 運動精度の向上, そして温 度，振動などの環境条件の整備が不可欠である.

\section{2 ステップ送りの測定}

リードの測定より，ナノメータオーダの位置決め分 解能が比較的容易に得られることが推測される。 そこ で，このことを確かめるために圧力比を 0.69 ，モー タ分割数を 12800 とし，フィードバックをかけない オープンループ制御により微少送り量を容量型变位計 により測定した．ただし，変位計の分解能，温度変化 や振動などの測定環境の不安定さのために, $10 \mathrm{~nm}$ 以 下の移動量の測定は困難であったので， 3 パルスのス テップ送りを $\mathrm{CW} ， \mathrm{CCW}$ それぞれ 5 回行った結果を 図 10 に示す．テーブル変位は駆動軸の軸線から左右 それぞれ約 $60 \mathrm{~mm}$ 隔たった 2 か所で測定されたもの である。

各ステップの最初にはモータ特性の影響と思われる オーバシュートが見られるが，テーブルの左右位置と

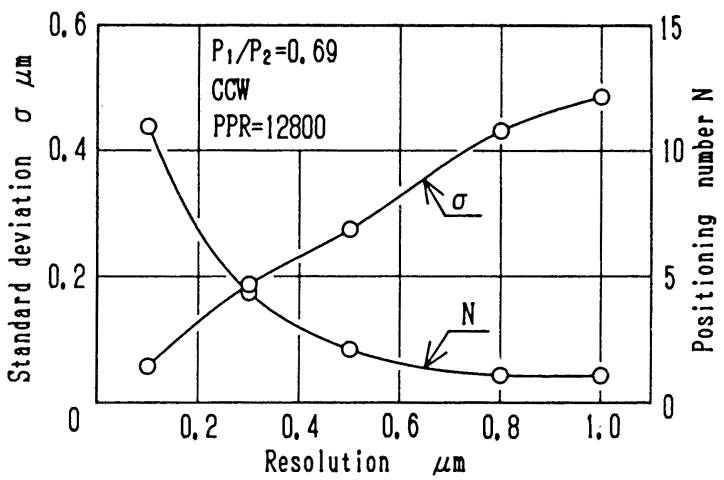

Fig. 11 Closed-loop positioning of the twist-roller friction drive

もほぼ同じ動きをしており，送り動作に伴うテーブル の姿勢変化, 駆動軸の回転方向が変わったときのロス トモーションなどの少ないことがわかる．ただし，温 度変化による零点ドリフトのためにテーブルの出発位 置と帰還位置とには若干の相違が見られた。この測定 に拈ける平均ステップ量は $17.9 \mathrm{~nm}$ であり, 図 9 の 計算值よりもやや大きかったが，ナノメータステップ の送りの行われていることが確認できた．各ステップ のばらつきは標準偏差で $3.7 \mathrm{~nm}$ であった。 したがっ て以上より，このッイストローラ摩擦駆動装置はナ， メータオーダの位置決め分解能を持つことが明らかで あり，図 9 の計算値はほぼ達成可能と考えて良いであ ろう。

\section{3 クローズドループによる位置決め制御}

図6のブロック線図のクローズドループを用いた フィードバック制御によって, $1 \mu \mathrm{m}$ ステップの位置 決めを種々の設定分解能で 100 回行った. このときの 圧力比は 0.69 , モータ分解能は 12800 , そしてテー ブル位置の測定には電気マイクロメータを用いた．図 11 には制御システムの設定分解能を変えたとさの テーブル停止位置の標準偏差 $\sigma$ と平均位置決め動作 回数 $N$ を示す. 位置決め動作回数が 2 以上とは, フィードバック制御により修正動作の行われたことを 示す.

設定分解能が $0.8 \mu \mathrm{m}$ 以上では修正動作は行われて 抢らず，停止位置は正規分布していた．設定分解能を 小さくするにつれて修正動作が行われるようになり， 停止位置の分布は次第に一様分布状に変わり, 停止位 置の標準偏差 $\sigma$ が設定分解能の $1 / \sqrt{3}$ に近づくこと がわかった．したがって位置決め精度を $3 \sigma て ゙$ で価す ると, 設定分解能が $0.8 \mu \mathrm{m}$ 以上では図 8 のオープン ループ制御と大差ないが，設定分解能を $0.5 \mu \mathrm{m}$ 以下 にすることで位置決め精度をサブミクロンオーダにで 
きることがわかる.

ただし，設定分解能を小さくするにつれて修正動作 の回数が増加している．たとえば，設定分解能を 0.1 $\mu \mathrm{m}$ にすると， $3 \sigma$ は $0.17 \mu \mathrm{m}$ となりサブミクロンの 位置決め精度を示しているが, 修正動作は 10 回を越 している. 図11 の条件での位置決め分解能は図 9 に 示すように約 $5 \mathrm{~nm}$ であるにもかかわらず， $0.1 \mu \mathrm{m}$ 程度の設定分解能に打いてこのように頻繁に修正動作 が行われるのは，この位置決め装置の案内精度や温 度，振動などの環境条件が充分ではなく，リードが変 動しているためである。したがって，ッイストローラ 摩擦駆動方式の利点を生かしてょり高い位置決め精度 を実現するには，装置の部品精度，案内部の真直度， 平面度などの向上, 作動油温度の安定化, そして装置 台の防振対策などが必要であり，現在検討中である.

\section{5. ま と め}

従動軸を静圧支持したツイストローラ方式の摩擦駆 動部を持つ位置決め装置を試作してその特性を解析し た結果，次のことが明らかとなった。

（1）従動ローラ支持スラスト静圧軸受への供給圧 を変えることでリードを $100 \mu \mathrm{m}$ の範囲で設定 することができた。

（2）駆動モータを数万分の 1 回転で制御すること
でナノメータオーダの位置決め分解能を得ること ができた。

（3）フィードバック制御を行らことでサブミクロ ンオーダ位置決め精度を得ることができた.

以上よりッイストローラ方式摩擦駆動によって精密 位置決め機構の実現できることが確認された。

終わりに，本研究で用いた摩擦駆動装置の製作に協 力された鳥取大学工学部学生・牧野隆史氏, 斉藤憲一 氏, 扣よび鳥取大学実習工場, (株)不二越・精機部に 対し深く感謝いたします。

\section{参 考 文 献}

1）高橋道郎, 大塚二郎, 小野一也, 臼井 孝, 東福 真 : 摩擦駆動における精密位置決めの研究 (第 1 報), 精密工 学会誌, 54,4 (1988) 715 .

2）諸貫信行, 古川勇二：摩擦伝動による精密送り機構に関 する研究，精密工学会誌， 54, 11 (1988) 2113.

3）大塚二郎, 高橋道郎, 臼井 孝, 東福 真, 青木若人: 摩擦駆動における精密位置決めの研究 (第 2 報), 精密工 学会誌, 55, 1 (1989) 123.

4）山口将明, 清水弘幸, 竹内芳美, 稲田 久, 佐田登志 夫：摩摖駆動による精密送り装置の開発, 精密工学会誌, 56, 1 (1990) 146.

5）高橋道郎, 大塚二郎：摩擦駆動による精密位置決め, 精 密工学会誌, 56, 9 (1990) 1611.

6）三木プーリ(株)：リニアアクチュエータローリックス, 三木プーリ(株)カタログ，'89. 3-3, 000-I-RX-002 D.

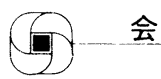

会

\section{報}

\section{0 年度第 1 回理事会議事}

開催期日 平成 3 年 4 月 24 日 (火), 17 時 30 分 20 時 30 分

場所 サンパークホテル会議室

議 事 1.1991 年度期理事会運営の基本方針の件

2. 1991 年度理事の職務分担の件

3. 1991 年度理事会および総務委員会開催 の件
4. 1991 年度精密工学会技術賞拈よび蓮沼 記念賞の審査委員会設置の件

5. 1991 年度支部活動費に関する件

6. 精密工学会地域別精密技術研究会設置承 認の件

7. 財団法人精密測定技術振興財団「高城 賞」受賞候補者推薦の件

8. 各部会・委員会報告の件

9. その他

（1）事務所のスペース有効活用

（2） 1991 年度春季大会決算報告

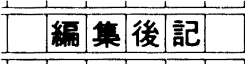

現在西側先進国によるサミットがロンドンで行われよ5 としている. 今回のサミットには, はじめてソ連との意見 交換が予定されているそらである. しかしソ連やドイッを はじめ最近の世界の変わりようはどうであろう。このよう な世界的な変化がもたらされた主な理由は, 多くの情報の すばやい伝達であるといわれている.

しかし，これらの情報が事実であるかどうかとなると極 めてあいまいである．ここで重要なことは情報が事実であ るかどらかではなく，われわれがこの情報を事実として受
け取り，行動しているということである.このよらな状況 で，実際にはないものでもあたかも存在するかのように 我々に影響を及ぼす。

今回特集した人工現実感も, コンピュータで現実感を 持った虚像を作り積極的に利用していこうというものであ る. 現在の人工現実感の話題の中心は, 虚像がどこまで実 像に迫れるかであるが，将来的には人間にとって虚像がど のよらな意味を持つのかといら極めて重要な問題も提起し てくるであろう．それはこの技術が特に人間を対象として いるからである.

今回の特集を読まれ，会員読者諸姉諸兄にとってはいか がだったでしょらか。（遠山茂樹・神田雄一） 